\title{
Psychometric Properties of the Cyber Dating Abuse Questionnaire
}

\author{
Jaqueline Gomes Cavalcanti ${ }^{1}$ \\ Maria da Penha de Lima Coutinho ${ }^{1}$ \\ Anderson Mesquita do Nascimento ${ }^{2}$ \\ Adriele Vieira de Lima Pinto ${ }^{3}$ \\ ${ }^{1}$ Instituto de Educação Superior da Paraíba \\ ${ }^{2}$ Universidade do Estado de Minas Gerais \\ ${ }^{3}$ Universidade Federal da Paraíba
}

\begin{abstract}
The present study aimed to know the validity and reliability of the Cyber Dating Abuse Questionnaire - CDAQ in the Brazilian context. For this purpose, two empirical studies were designed. Study $1(N=215)$ tested the psychometric parameters of CDAQ, using exploratory factorial analysis. Study $2(N=248)$ sought to gather additional evidences of validity and accuracy of CDAQ using confirmatory factor analysis. The results pointed to the two-factorial structure as the most relevant, with good internal consistency indexes observed. In addition, CDAQ demonstrated convergent validity through meaningful associations with face-to-face abuse in love relationships (CTS2) and overall satisfaction in relationships. Furthermore, it is concluded that CDAQ presents itself as a valid and reliable measure, useful for investigating digital abuse in love relationships in the Brazilian population.

Keywords: intimate partners violence; digital aggression; technology; validity.
\end{abstract}

\section{Resumo}

Parâmetros Psicométricos do Questionário de Abuso Digital no Namoro

O presente estudo teve como objetivo conhecer a validade e fidedignidade do Questionário de Abuso Digital nos Relacionamentos Amorosos - QADRA no contexto brasileiro. Para isso, foram delineados dois estudos empíricos. O estudo $1(N=215)$ testou os parâmetros psicométricos do QADRA por meio da análise fatorial exploratória. O estudo $2(N=248)$ buscou reunir evidências adicionais de validade e precisão da EAC por meio da análise fatorial confirmatória. Os resultados apontaram para a estrutura bifatorial como a mais pertinente, sendo observados bons índices de consistência interna. Além disso, o QADRA demonstrou validade convergente por meio de associações significativas com o abuso presencial nos relacionamentos amorosos (CTS2) e a satisfação global nos relacionamentos. Ademais, conclui-se que o QADRA apresenta-se como uma medida válida e fidedigna, útil para investigação do abuso digital nos relacionamentos amorosos na população brasileira.

Palavras-chave: violência entre parceiros íntimos, agressão digital, tecnologia, validade

\section{Resumen}

Parámetros Psicométricos del Cuestionario de Abuso Digital en Relaciones Amorosas

El presente estudio tuvo como objetivo conocer la validez y confiabilidad del Cuestionario de Abuso Digital en las Relaciones Amorosas - QADRA en el contexto brasileño. Para ello, se delinearon dos estudios empíricos. El estudio 1 ( $\mathrm{N}=215)$ probó los parámetros psicométricos del QADRA a través de análisis factorial exploratorio. El estudio $2(\mathrm{~N}=248)$ buscó reunir evidencias adicionales de validez y precisión de la EAC a través de análisis factorial confirmatorio. Los resultados apuntaron para una estructura bifactorial como la más pertinente, siendo observados buenos índices de consistencia interna. Además, el QADRA demostró validez convergente a través de asociaciones significativas con el abuso presencial en las relaciones amorosas (CTS2) y satisfacción global en las relaciones. Además, se concluye que el QADRA presenta una medida válida y fidedigna, útil en la investigación de abuso digital en relaciones amorosas de la población brasileña.

Palabras clave: violencia entre parejas íntimas; agresión digital, tecnología; validez

\section{Introduction}

Intimate Partner Violence (IPV) has been recognized worldwide as a public health problem because of its high frequency as well as the harmful consequences for those involved (Behnken, Duan, Temple, \& Wu, 2018; Moraes et al., 2017). With the increasing use of the information and communication technologies (ICT), IPV has been exceeded the face-to-face sphere, emerging in the virtual modality under different forms, among them, the Cyber Datting Abuse (CDA), Borrajo, Gámez-Guadix, Pereda \& Calvete, 2015a, SmithDarden, Kernsmith \& Lathrop, 2017; Zweig, Dank, Yanher \& Lachman, 2013).

The CDA (Cyber Dating Abuse or Cyber Dating Aggression) is related to threats, insults, humiliations or jealousy behaviors with the intention of provoking anguish in the partner through technology (Borrajo et 
al., 2015a; Flach \& Deslanches, 2017; Van Oytsel et al., 2016). For Borrajo et al (2015a), CDA can occur in two ways: (1) Direct Aggression concerning the aggressive act with intent to injure the (ex) partner; and (2) Control/Monitoring that consists in the use of electronic means to control the (ex) partner.

Although $\mathrm{CDA}$ is indicated as co-occurring with IPV (Borrajo et al., 2015a, Watkins et al., 2016; Wolford-Clevenger et al., 2016), it may be even more prevalent due to the possibility of such abuse can occur at any place or time (even after the termination of the relationship); without the necessity of the presence of the aggressor (Melander 2010), considering that it can reach a larger audience (Runions, Shapka, Dooley, \& Modecki, 2013).

In spite of this, the study proposed in the United States by Zweig et al., (2013) with 5,645 individuals indicated that $1 / 4$ of the young people, between 7 th and 12th grade, experienced virtual aggression during their courtship in the last year. In the same country, another study pointed out that $34,6 \%$ of the students emphasized that they were victims of a digital sexual coercion, while 53,8\%, of Monitoring/Digital Control (Reed, Tolman \& Ward, 2017). In the same direction, Smith et al (2018), during a research with young Canadians in high school, showed high percentages of involvement in victimization (35.8\%), perpetration $(33.0 \%)$, and in both forms $(27,2 \%)$.

Also prevalence data were verified in Spain, indicating that $57,2 \%$ of the students, between the ages of 18 and 30, were victims of bullying phone calls, and $27.4 \%$, via internet; while $47.6 \%$ were attacked by phone, and $14 \%$ by internet. On the other hand, the study of Borrajo et al., (2015), with 788 young Spaniards, aged between 18 and 30, found rates ranging from 10 to $82 \%$ of perpetration; and $18.5 \%$ to $83.5 \%$ of victimization (Durán, \& Martínez Pecino, 2015).

Researches also demonstrate consequences related to this phenomenon, which can lead to: sleep disorders, depressive and anxious symptoms, suicidal ideation, involvement in delinquent behavior, and negative implications for school performance; inferior satisfaction indexes with relationships; low self-esteem and emotional distress (Flach \& Deslanches, 2017; Hancock et al., 2017; Smith et al., 2018). These findings highlight the relevance of the theme, as an object of study, considering the growing involvement of young people and adults in this phenomenon, as well as the negative implications on the biopsychosocial health of those involved. In this sense, evaluation measures have been developed, especially seeking to understand the antecedents and consequences of the CDA.

However, the national literature is still rare. There are only two articles published: a review article on the subject, from Flach and Deslanches (2017) and an article on analysis of textual productions of Flach and Deslanches (2019). As for the international literature, a scientific production is in its initial phase. In the review proposed by Cavalcanti and Coutinho (2019), were found in the period from 2008 to 2018, 5 measures with validity and reliability reports, namely: Cyber Dating Abuse Questionnaire (CDAQ, Borrajo et al., 2015a); Cyberdating Q_ A (Sánchez et al., 2015); Cyber Aggression in Relationships Scale (CARS, Watkins et al., 2016), Partner Cyber Abuse Questionnaire of Hamby (2013; WolfordClevenger et al., 2016) and Escala de Ciber-Violencia en Parejas Adolescentes (Cava \& Buelga, 2018), with a greater predominance of CDAQ (Borrajo et al., 2015c).

The Cyber Dating Abuse Questionnaire (CDAQ Borrajo et al., 2015a) evaluates both victimization and perpetration, in relation to the partner or ex-partner, through two factors: Direct Aggression and Monitoring / Control. This scale has a satisfactory internal consistency for both factors, evaluated by Cronbach's alpha: Direct Aggression (victimization $=0.84$, perpetration $=0.73$ ), and Monitoring/ Online Control (victimization $=0.87$, perpetration $=0.81)$. In the same year, there is The Cyberdating $Q_{-} A$ questionaire (Sánchez et al., 2015) which consists of 45 items that cover six factors with good indexes of Cronbach's alpha: online intimacy $(a=0.71)$, emotional communication strategies ( $a=0.84)$, digital dating practices ( $a$ $=0.75)$, online control $(a=0.85)$, online envy $(a=0.79)$ and online intrusive behavior $(a=0.84)$. On the other hand, the Cyber Aggression in Relationships Scale (CARS, Watkins et al., 2016) presents 34 items that evaluate perpetration and victimization in relation to the current partner, which encompass three factors: psychological cybernetic aggression; sexual cyber bullying and cybernetic stalking. Regarding Partner Cyber Abuse Questionnaire of Hamby (2013) this questionnaire corresponds to a unifactorial victimization measure composed of nine items that together presented an acceptable Cronbach's alpha $(a=0,72)$ (WolfordClevenger et al., 2016). Finally, more recently, it was developed the Escala de Ciber-Violencia en Parejas Adolescentes (Cava \& Buelga, 2018) which consists of 10 items divided equally between two factors: virtual aggression and virtual control, that shows good Cronbach's alpha indexes (between 0.92 and 0.97). It should be 
noted that this measure presents one version for perpetration and another one for victimization.

Due to the measures found, CDAQ was chosen (Borrajo et al., 2015a) because of its ability to evaluate both victimization and perpetration behaviors; as well as for considering the perspective of partners or expartners. In addition, this instrument considers CDAQ as a multidimensional construct consisting not only of control actions, but also of direct aggressions, considering behaviors such as threats, identity theft, control and humiliation.

It is also worth noting that there are studies with this scale in other contexts such as Belgium (Ouytsel, Ponnet, \& Walrave, 2016, Ouytsel, Ponnet, Walrave, \& Temple, 2016) and Mexico (García- Sánchez, GuevaraMartínez, Rojas-Solís, Peña-Cárdenas, \& Cruz, 2017). More recently, there is a validation study in Portugal, which pointed to good indexes of adjustment and satisfactory internal consistency (Cronbach's alpha ranging between 0.84 and 0.91; Caridade \& Braga, 2019).

Besides, once detected an advance of the technology and its increasing use in the love relationship, it is verified that the virtual aggression between couples has been recurrent, exposing victims to a greater vulnerability and generating severe implications to those involved. Under these circumstances, having an instrument that evaluates this phenomenon can help in the tracking and better interventions in this problem. Despite, there is no specific evaluation measure for intimate partners of digital abuse in the Brazilian context. In this sense, this study sought to know the validity and reliability of the Cyber Dating Abuse Questionnaire - CDAQ.

Considering these instances, the present study depart from the following hypotheses: a) it is expected to confirm the factorial structure with 2 dimensions; b) CDAQ is expected to achieve satisfactory results in terms of internal consistency; c) CDAQ is expected to demonstrate convergent validity through positive association with a face-to-face measure of the relationship abuse; and negative for satisfaction in loving relationships; d) it is also expected to find higher prevalence rates of digital abuse in the romantic relationships considering the Control factor than in the direct Aggression. To test these hypotheses, a cross-validation was performed, through two empirical studies.

\section{Study 1 - Exploratory Factorial Structure of the Cyber} Dating Abuse Questionnaire

It was a cross-sectional psychometric study with the objective of finding the evidences of its validity and reliability - internal consistency - through Cronbach's Alpha.

\section{Method}

\section{Participants}

In this study, 215 individuals participated, with an average age of $28.27(D P=6.05$; ranging from 18 to 54 years old), most of them women $(74.9 \%)$; heterosexuals $(84.7 \%)$, with postgraduate education $(56.3 \%)$; and in a current relationship (69.3\%). Among these, 53\% lived in the Northeast region, $24.2 \%$ in the Southeast region, $15.8 \%$ in the South region, $4.2 \%$ in the North region and $2.8 \%$ in the Midwest region. In addition, the majority of the sample assumed spending more than 6 hours a day on the internet $(34.9 \%)$, and on the cellphone $(28.8 \%)$.

\section{Instruments}

Cyber Dating Abuse Questionnaire - (CDAQ Borrajo et al., 2015a). This instrument was prepared in Spain and offers two versions: one for victimization and the other for perpetration. It is composed of 20 items, which are distributed in two factors: Direct Aggression (DA, 11 items) and Control / Monitoring (C, 9 items. Direct Aggression refers to aggressive acts intended to injure the (former) partner (e.g. I wrote a comment on the wall of a social network to insult or bumiliate my partner, or former partner). Control / Monitoring, in turn, consists of the use of electronic means to control the (former) partner (e.g. I have controlled my partner or former partner's friendships in the social networks). This standard aims to find out how often participants experienced abuse behaviors online performed by their (former) partners over the past year through a 5-point scale, which ranges from $1=$ " never" to $6=$ " usually". The total scores range from 20 to 120 , where higher values indicate a higher frequency of digital abusive behaviors, either as a victim, on the scale of victimization, or as an aggressor, on the scale of perpetration. The original scale did not indicate to a cut-off point.

In its original study, CDAQ presented evidences of convergent validity with factors of traditional violence among couples; and cyberbullying, pointing to positive correlations between 0.16 and 0.40 (all with $\mathrm{p}$ $<0.001)$; as well as a satisfactory internal consistency for both factors: Direct aggression (victimization $\alpha=$ 0.84; perpetration $\alpha=0.73$ ); and Control / Monitoring (victimization $\alpha=0.87$, perpetration $\alpha=0.81$ ). Sociodemographic questionnaire - to distinguish participants as to 
gender, education, sexual orientation, whether they are in a current relationship; daily use of cell phone and computer; which region of the country they live in.

\section{Procedures}

Authorized by the authors of the original questionnaire, the translation and adaptation of CDAQ was started, based on the process suggested by Hutz, Bandeira and Trentini (2015). In this sense, the English (original language) into Portuguese translation was initially performed by three bilingual psychologist researchers, with fluent English mastery and that had detailed knowledge of the scale. Next, the translated texts were compared, performing a second standardization of the scale adjusting expressions that could lead to doubts. Subsequently, the scale version was applied in a pilot study with 20 university students aiming to assess the understanding of the questions and the vocabulary presented in the translation of the scale. It was requested, when completing the answers, that each student pointed out their possible doubts or difficulties. After this procedure, some expressions were modified and the final version of the scale was applied.

Subsequently, participants were invited to answer a questionnaire via electronic form in the Google Docs feature. This investigation instrument was shared in social networks and academic communities. Before starting the research, the participant was informed about the purpose of the study and oriented about the voluntary and confidential nature of the work. If the person agreed to respond, the questionnaire was made available to the volunteer. The average time to filling in was 20 minutes.

It should be noted that all procedures used in the study were approved by the Research Ethics Committee of the Federal University of Paraiba (CAAE: 80433517.4.0000.5188), and followed the norms of resolution 466/2012 and 510/2016 of the Research Ethics Committee with Human Beings.

\section{Data analysis}

First of all, we sought to know the adequacy of the inter-correlations matrix to perform an analysis of the main components, using two indicators: the Kaiser-Meyer-Olkim criterion (KMO), which should be higher than 0.60 to support the performing of this analysis, and Bartlett's Sphericity Test, whose chi-square value needs to be statistically significant (Tabachnick \& Fidell, 2013). Later, the Parallel Analysis (PA) with optimal implementation (Timmerman \&
Lorenzo-Seva, 2011) was used to decide the number of factors to be extracted. We generated 500 simulations with the same characteristics of the empirical data matrix (215 participants and 20 items). The factor is retained when the variance explained by the PA is greater than the variance explained by the empirical data matrix. Then, for each scale of the questionnaire, an exploratory factorial analysis was performed, adopting the Minimum Rank Factor Analysis (Shapiro \& ten Berge, 2002) and Varimax orthogonal rotation. All these procedures were performed using the Factor 10.3 program (Lorenzo-Seva \& Ferrando, 2006). Finally, the reliability of the measurement was estimated through the internal consistency of the items, using the Cronbach's alpha index (a). This index was calculated using the psych package (Revelle, 2018) in the R program (R Development Core Team, 2011).

\section{Results}

Since the CDAQ is composed of two scales (victimization and perpetration), the results will be presented individually for each of them. For the victimization scale, the Kaiser-Meyer-Olkim (KMO = $0.88)$ and the Bartlell sphericity test $\left[\chi^{2}(190)=2074,1\right.$; $p<0.001)$ indicated the suitability of the measure to perform the Exploratory Factor Analysis (EFA). The perpetration scale also demonstrated suitability of its factorization matrix through EFA, as observed in the KMO value $(0.83)$ and the Bartlett sphericity test $\left[\chi^{2}\right.$ $(190)=1921.4 ; \mathrm{p}<0.001)$. Then, the PA recommended the extraction of two factors in both scales of the questionnaire, considering that the explained variance of the third factor of the empirical data matrix was inferior to the one obtained through the random data matrices. Table 1 summarizes the results for the first five factors.

Thereafter, a new EFA was performed, this time setting two factors to be extracted. A minimum factorial load of 0.40 was used so that the item was retained in the factor. Besides that, to sustain equivalence between the scale versions, those items retained on only one of the scales of the questionnaire were also excluded. The factorial loads and the measure's internal consistency indexes are presented in Table 2.

Relating to the victimization scale, EFA revealed a two-factor solution. The first factor explained $40 \%$ of the variance. When analyzing the content of items that presented factorial loads above the cut-off point for this factor, it was observed that such items refer to behaviors in which the partner, or former partner, 
Table 1.

Parallel analysis of the Cyber Dating Abuse Questionnaire $(N=215)$

\begin{tabular}{lllll}
\hline \multicolumn{3}{l}{ Victimization } & Perpetration \\
\hline & $\begin{array}{l}\text { Variance explained in the } \\
\text { empirical matrix (\%) }\end{array}$ & $\begin{array}{l}\text { Variance explained by } \\
\text { AP }(\%)\end{array}$ & $\begin{array}{l}\text { Variance explained in the } \\
\text { empirical matrix }(\%)\end{array}$ & $\begin{array}{l}\text { Variance explained by } \\
\text { AP }(\%)\end{array}$ \\
\hline $1^{*}$ & 40,0 & 10,3 & 32,6 & 10,3 \\
$2^{*}$ & 11,5 & 9,4 & 10,7 & 9,4 \\
3 & 7,1 & 8,8 & 8,3 & 8,7 \\
4 & 6,4 & 8,2 & 6,6 & 8,1 \\
5 & 5,8 & 7,7 & 6,0 & 7,6 \\
\hline
\end{tabular}

Table 2.*

Exploratory Factorial Structure of the Cyber Dating Abuse Questionnaire $(N=215)$

\begin{tabular}{ccccc}
\hline & \multicolumn{2}{c}{ Victimization } & \multicolumn{2}{c}{ perpetration } \\
\hline item 18 & Direct Aggression & Control/Monitoring & Direct Aggression & Control/Monitoring \\
item 6 & $0,70^{*}$ & $-0,08$ & $0,60^{*}$ & $-0,03$ \\
item 4 & $0,65^{*}$ & $-0,03$ & $0,55^{*}$ & 0,16 \\
item 15 & $0,60^{*}$ & 0,23 & $0,80^{*}$ & 0,03 \\
item 16 & $0,59^{*}$ & 0,11 & $0,62^{*}$ & 0,31 \\
item 9 & $0,57^{*}$ & 0,22 & $0,68^{*}$ & 0,06 \\
item 11 & $0,55^{*}$ & 0,39 & $0,62^{*}$ & 0,30 \\
item 5 & 0,16 & $0,82^{*}$ & 0,01 & $0,86^{*}$ \\
item 20 & 0,18 & $0,79^{*}$ & 0,12 & $0,69^{*}$ \\
item 17 & 0,30 & $0,77^{*}$ & 0,21 & $0,77^{*}$ \\
item 19 & 0,21 & $0,77^{*}$ & 0,09 & $0,84^{*}$ \\
item 1 & 0,39 & $0,68^{*}$ & 0,32 & $0,56^{*}$ \\
item 13 & 0,31 & $0,63^{*}$ & 0,28 & $0,56^{*}$ \\
item 7 & 0,36 & $0,57^{*}$ & 0,34 & $0,51^{*}$ \\
item 2 & 0,21 & $0,47^{*}$ & 0,21 & $0,44^{*}$ \\
item 3 & 0,29 & 0,45 & 0,28 & 0,37 \\
item 8 & 0,18 & 0,43 & 0,25 \\
item 10 & 0,49 & 0,15 & 0,20 & 0,17 \\
item 12 & 0,59 & 0,13 & 0,54 & 0,32 \\
item 14 & 0,53 & 0,51 & 0,04 & 0,01 \\
\hline
\end{tabular}

* item retained in factor

intends to cause direct damage to the victim (e.g. My partner, or former partner, spread rumors, gossip and/or jokes about me using new technologies with the intent to make fun of me), so this factor was titled "Direct Aggression". The second factor explained $11.5 \%$ of the variance and included items related to the partners, or former partners, control or invasion of the victim's privacy (e.g. My partner or former partner inspected my social networks, Whatsapp or email without my permission), being titled "Control/ Monitoring". Regarding the perpetration scale, the 
EFA also revealed the structure of two factors, similar to those found in the victimization one. The first one, "Direct Aggression" explained 32.6\% of the total variance, retaining six items. These items refer to behaviors intended to inflict direct harm to the partner, or former partner, such as humiliation and threats (e.g. I wrote a comment on a social network feed to insult or bumiliate my partner, or ex-partner). The second factor explained $10.7 \%$ of the variance and retained eight items. It included items that are related to controlling behaviors of the partner, or former partner, (e.g. I controlled my partner or former partner's friendships in social networks), and for this reason it was named "Control/Monitoring".

It is worth mentioning that item 14 presented factorial loads above the cut-off point for both factors, in both scales, so being ex cluded from the subsequent analyzes. In addition, items 2, 3, 8, 10 and 12 met the inclusion criterion in one of the scales, but not in the other. To maintain the equivalence between scales, these items were also excluded from the following analyses. After such exclusions, Cronbach's alpha was calculated for each factor. Both the victimization scale (AD $\alpha=$ $0.78, \mathrm{C} \alpha=0.90)$ and the perpetration scale (AD $\alpha=$ 0.80; $\mathrm{C} \alpha=0.86$ ) reached internal consistency indexes above the recommended in the literature.

The prevalence of involvement in digital abuse was also calculated, with Direct Aggression being found at $15.5 \%$ for perpetration and $24.7 \%$ for victimization. As for the prevalence of Control/Monitoring, 89.3\% reported having perpetrated such behavior, while $81.9 \%$ had been victims. Next, we sought to gather additional evidences of the psychometric adequacy of the measure, testing the adjustment of the model found to a new dataset, as well as its convergent validity with other measures.

\section{Study 2 - Confirmatory Factorial Structure of the} Cyber Dating Abuse Questionnaire

This study was a cross-sectional psychometric study that aimed gathering additional evidence of validity (factorial and convergent) and reliability of the CDAQ in a new sample, from the confirmatory factorial analysis (CFA), person correlation with other measures, and Cronbach's Alpha.

\section{Method}

\section{Participants}

In this study, 248 individuals participated, with an average age of $27.80(\mathrm{SD}=6.42$; ranged from 18 to
56 years), of which the majority were women (84.3\%); heterosexuals $(85.9 \%)$, with postgraduate education $(52 \%)$; and currently in a relationship $(72.2 \%)$. Among them, $58.5 \%$ lived in the Northeast region, $22.2 \%$ in the Southeast region, $11.7 \%$ in the South region, $4 \%$ in the Midwest region, and 3, 6\% in the North region. In addition, the majority emphasized spending more than 6 hours a day on the internet $(37.5 \%)$, and on the cellphone $(33.9 \%)$.

\section{Instruments}

Cyber dating abuse questionnaire - (CDAQ Borrajo et al., 2015a) described in study 1, nevertheless, considering the item distribution generated by the exploratory factorial analysis.

Conflict Tactics Scales (CTS-2) was validated for Brazil by Moraes, Hasselmann and Reichenheim (2002) and evaluates different conflict resolution tactics adopted by intimate partners. It is composed of pairs of items, distributed in 9 factors: severe sexual coercion, minor sexual coercion, severe physical violence, minor physical violence, severe injury, minor injury, negotiation, severe psychological aggression, minor psychological aggression. The CTS-2 response scale ranged from 1 - "This never happened" to 8-" "More than 20 times from a year ago until now." The internal consistency indexes of the scale were satisfactory as for the validation study (between 0.65 and 0.82) and for this study (between 0.61 and 0.91$)$.

Overall satisfaction in relationships scale was elaborated by Rusbult (1983) and measures the overall satisfaction of a relationship. It is composed of three items answered in the Likert 5-point format, 1 = "strongly disagree" and $5=$ "strongly agree". The Portuguese version of the scale, translated and validated by Wachelke, Andrade, Souza and Cruz (2007), indicated a Cronbach's alpha coefficient of 0.90 . A similar index was reached in this study $(\alpha=0.96)$.

Sociodemographic questionnaire. Described in study 1.

Procedures

The same procedure of online data collection from study 1 was followed; however, the application time was longer, 20 minutes, considering that other measures were added.

\section{Data analysis}

Initially, via confirmatory factorial analysis, the two factor models were tested for both scales, as observed in Study 1. For that, the Maximum Likelihood 
(ML) estimative was adopted. These analyses were performed with Mplus 6.12 (Muthén \& Muthén, 2010). The verification of the adjustment of the models to the empirical data took into account the following indicators: Comparative Fit Index (CFI) and Tukey-Lewis Index (TLI), considering values of 0.90 or higher as an indication of adequate adjustment; the Root Mean Square Error of Approximation (RMSEA), which value must be less than 0.05 , admitting up to 0.10 as upper limit of its confidence interval (CI90\%); and the $\chi^{2}(\mathrm{gl})$ at the significance level of 0.05 . To compare the models, we observed the difference between their chi-squares $\left(\chi^{2}\right)$ and the Consistent Akaike Information Criterion (CAIC), in which the most adjusted model presents a lower index. The internal consistency of the factors was tested from the Cronbach's alpha (a) obtained through the R program (R Development Core Team, 2011), using the psych package (Revelle, 2018), and Composite Reliability (CR) considering the standardized saturations of the items from the confirmatory factorial analysis (Gouveia $\&$ Soares, 2015). Subsequently, to test the convergent validity, pearson correlation indexes with a significance level of 95\%, calculated using the Hmisc (Harrel \& Dupont, 2018) package, also available through the $\mathrm{R}$ program, were used.

\section{Results}

The initial adjustment of the two-factor model of the victimization scale presented the following indexes: $C F I=0.82, T L I=0.78$, RMSE $A=0.13(\mathrm{IC} 90 \%=$ $0.12-0.14)$ e $\chi^{2}(76)=392.96, p<0.001$. However, we decided to re-specify the model when observing the Modification Indexes (MI). Such indexes indicated an error variance shared between items 11 (My partner or former partner inspected my social networks, Whatsapp or email without my permission) and 17 (My partner or former partner checked my phone without my permission), which MI was of 79.48. After allowing the covariation of these errors, the data presented higher indexes of adjustment to the model [CFI=0.86,TLI=0.83, RMSE $A=$ $0.11(\mathrm{IC} 90 \%=0.10-0.12)$ e $\left.\chi^{2}(75)=310,77, p<0.001\right]$, although they still remained below the cut-off points recommended by the literature. To settle any doubts about the factorial structure of the model, it was compared to a model with all the items saturated in a single factor. The results showed that the two-factor model presented a better adjustment to the data $\left[\Delta \chi^{2}(1)=\right.$ 122.74, $p<0.001$, AIC (two-factor model) $=9518.03$, AIC (single-factor model $)=9638.77)]$.
Regarding the Perpetration scale, the initial adjustment of the two-factor model presented the following adjustment indexes: $C F I=0.79, T L I=0.71, R M S E A$ $=0.11(\mathrm{IC} 90 \%=0.10-0.12)$ e $\chi^{2}(76)=315.70, p<$ 0.001. In this scale, it was also noted that items 11 (I inspected my partner's social networks, Whatsapp or email without his/her permission) and 17 (I inspected my partner's or former partner's cell without his permission) showed a MI of 85.28. Therefore, we decided to re-specify the model to allow covariation between the errors of the mentioned items. After this procedure, the data had higher indexes of adjustment to the model [CFI $=0.85$, TLI $=0.82$, RMSE $A=0.09(\mathrm{IC} 90 \%=0.08-0.11)$ e $\chi^{2}(75)=244.22$, $p<0.001]$, but in the same way of the victimization scale, also did not reach the cut-off points recommended by the literature. To resolve any doubts about the factorial structure of the model, it was compared to a model with all the items saturated in a single factor. The two-factor model presented a better fit to the data $\left[\Delta \chi^{2}(1)=112.62\right.$, AIC (two-factor model $)=8302.96$, AIC (single-factor model) $=8413.58$ ). Figure 1 shows the models for both scales with respective saturations for each item.

All saturations were positive and non-zero $(\lambda \neq 0 ; p$ $<0.001)$. In the victimization scale, the Direct Aggression factor had saturations varying between 0.35 and 0.69, presenting Cronbach's alpha of 0.71 and a CR of 0.71. On the other hand, in the Control / Monitoring factor, saturations ranged from 0.58 to 0.81 , resulting in $\alpha$ of 0.92 and a CR of 0.91 . In the perpetration scale, the Direct Aggression factor had saturations varying between 0.16 and 0.77 , presenting a Cronbach's alpha of 0.67 and a CR of 0.69 . On the other hand, in the Control / Monitoring factor, saturations ranged from 0.33 to 0.74 , resulting in $\alpha$ of 0.84 , and a CR of 0.83 .

In order to investigate the convergent validity of CDAQ with the Conflict Tactics Scale and the Global Satisfaction Scale in relationships, the correlation between these instruments was analyzed. For victimization, it was verified that the Direct Aggression factor correlated positively with the CTS2 dimensions: sexual coercion $(r=0.37)$; psychological aggression $(\mathrm{r}=$ $0.51)$; physical aggression $(r=0.36)$; injury $(r=0.22)$; and negatively with overall satisfaction in relationships $(r=-0.48)$, all with $p<0.01$. Regarding the Control/ Monitoring factor, it presented a positive correlation with the CTS2 dimensions: sexual coercion $(r=0.20)$; psychological aggression $(r=0.36)$; physical aggression $(r=0.27)$; injury $(r=0.17)$; and negatively with overall satisfaction in relationships $(r=-0.28)$, all with $p<0.01$. 

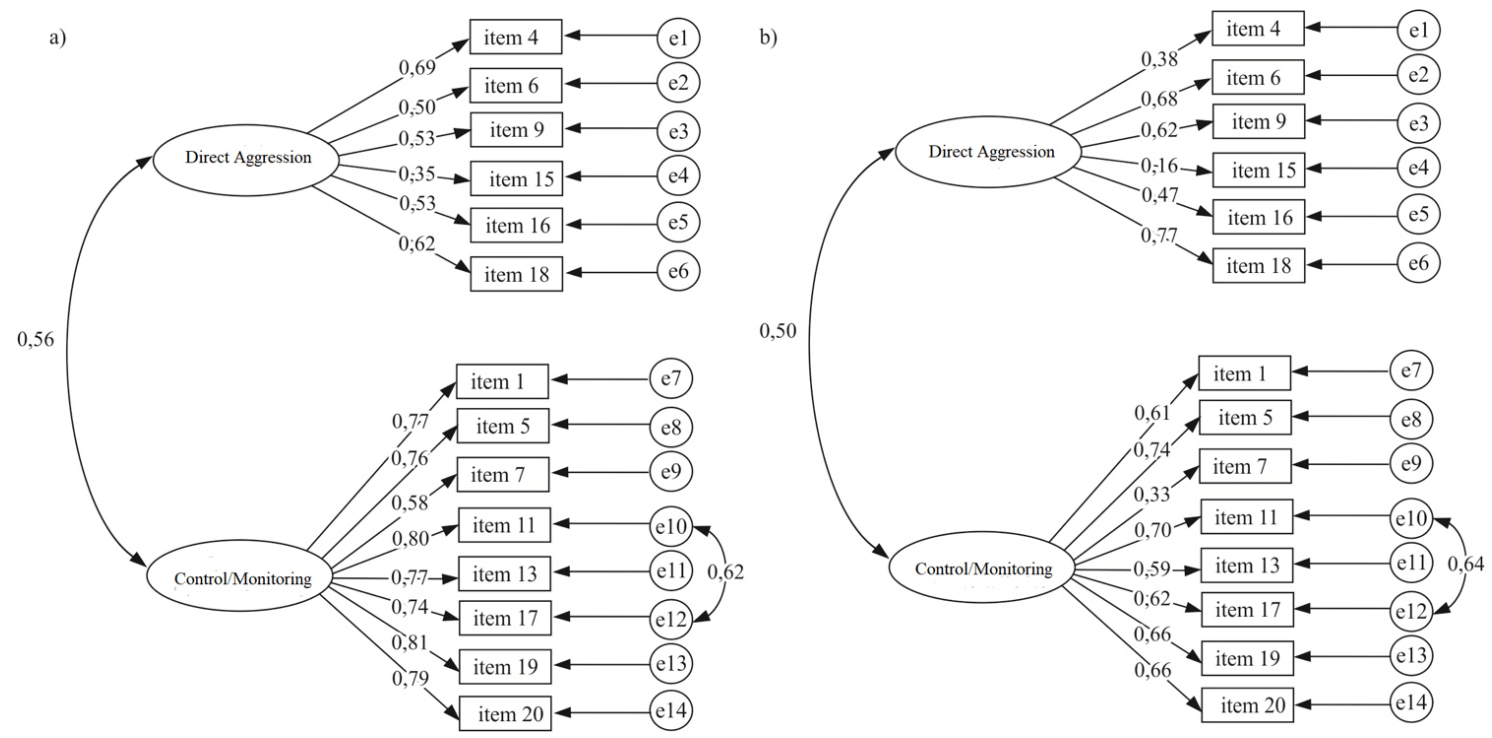

Note. a) victimization scale; b) perpetration scale.

Figure 1. Factorial Confirmatory Structure of Cyber Dating Abuse Questionnaire $(\mathrm{N}=248)$

As for perpetration, it was verified that the Direct Aggression factor correlated positively with the CTS2 dimensions: sexual coercion $(r=0.29)$; psychological aggression ( $\mathrm{r}=0.57)$; physical aggression $(r=0.43)$; injury $(r=0.31)$; and negatively with overall satisfaction in relationships $(r=-0.36)$, all with $p<0.01$. Concerning the Control / Monitoring factor, it presented a positive correlation with the CTS2 dimensions: sexual coercion $(r=0.42)$; psychological aggression ( $r=0.42)$; physical aggression $(r=0.36)$; injury $(r=0.37)$; and negatively with overall satisfaction in relationships $(r=-0.30)$, all with $p<0.01$.

Finally, we analyzed the cyber abuse frequencies from the sample taken at this study, and a prevalence of $18.5 \%$ was verified for the participants who indicated to have perpetrated Direct Aggression; and $24.6 \%$ who reported having been victims of Direct Aggression. Regarding the prevalence of Control/ Monitoring, an index of $83.5 \%$ was found for perpetrators and $80.2 \%$ for victims.

\section{Discussion}

Considering the objective of this study, that was to know the psychometric properties of the Cyber Dating Abuse Questionnaire (CDAQ) in the Brazilian context, it is considered to be reached. As for the factorial structure of the CDAQ, study 1, through exploratory factorial analysis, confirmed the study hypothesis, which postulated that the CDAQ would be formed by two dimensions, as pointed out in the original study (Borrajo et al., 2015), suggesting that this measure has construct validity, since the observed factors are aligned with the expected (Pacico \& Hutz, 2015). Although two factors emerged consistently with those found by Borrajo et al., (2015), in this study such dimensions retained fewer items; excluding item 14, as it presents factorial loads above the cut-off point; and items 2, 3, 8, 10 and 12 for failing to meet the criterion on only one of the two scales.

Regarding the CDAQ dimensionality, the two-factor structure was supported in study 2 , via confirmatory factorial analysis, in which indexes were found to approximate desirable ones (for example, CFI $>.90$, TLI> .90 and RMSEA <.08; Byrne, 2010). Even if such indexes are not the best, it should be considered that these indexes are not static (Brown, 2006), varying according to the model (Hu \& Bentler, 1999). Furthermore, it should be noted that, although there is a strict attention to translation and back-translation, according to procedures indicated by Hutz et al., (2015), aspects concerning culture may have influenced the way the phenomenon studied is understood. In other words, the way people understand the items may not be invariant.

As for the internal consistency of study 1 and 2, we find Cronbach's alphas (between 0.67 and 0.92) similars to those found in the original study (between 0.73 and 0.87; Borrajo et al., 2015a), pointing to positive precision 
indexes (Kline, 2013); and a satisfactory composite reliability, in study 2 (Gouveia \& Soares, 2015). These findings converge to the second hypothesis of this study, as well as values similar to or higher than those of other measures that evaluate the ADRA (between 0.71 and 0.85, Hamby, 2013, Sánchez et al., 2015).

The convergent validity of CDAQ with the CTS2 dimensions revealed, in general, positive and statistically significant correlations (between 0.17 and 0.57 ) which are in accordance with previous investigations (Borrajo et al., 2015a, Watkins et al., 2016; WolfordClevenger et al., 2016; Zweig et al., 2013). That is, digital abuse victims and perpetrators tend to be targets and perpetrators of traditional violence in the form of psychological, physical, sexual, and injury means. Concerning this, studies have shown that the cybernetic form can present itself as a possible precursor variable or a continuation of physical aggression (Marganski \& Melander, 2015; Melander, 2010). Among the types of physical and psychological aggression, it was the one that presented the greatest association with digital abuse (between 0.36 and 0.57 ), as was also reported in the study by Borrajo et al., (2015a) (between 0.28 and 0.47) and in previous studies (Marganski \& Melander, 2015, Watkins et al., 2016), corroborating the authors view that the ADRA and psychological abuse among couples are types of overlapping aggressions (Melander, 2010 Schnurr et al., 2013).

Likewise, confirming the third hypothesis of the study, concerning the convergent validity of the CDAQ with the global satisfaction scale in relationships, negative associations were found that ranged from 0.28 to 0.48 , which, according to research data, suggests that perpetrators and victims of digital abuse tend to have lower satisfaction in relationships (Borrajo et al., 2015a, Watkins et al., 2016; Paiva, Pimentel, \& Moura, 2017). Such data allow us to say that participants involved in digital violence present a negative evaluation of satisfaction in relationships. Satisfaction in relationships has been pointed out as a central characteristic in romantic relationships, and can significantly interfere in the lives of those who are involved, and may have negative implications for well-being and satisfaction with life, sleep, and mental health (Neves \& Duarte, 2015; Scorsolini-Comin \& Santos, 2010, Troxel et al., 2017).

Finally, in relation to the prevalence of CDA involvement, higher rates than those of the original study (Borrajo et al., 2015a) were observed, since, in the original study, the incidence rates ranged from 10 to $82 \%$; in this study, they ranged from $15.5 \%$ to $89.3 \%$; in relation to victimization, while the original study indicated indexes between $14 \%$ and $75 \%$; the present study found rates between $24.6 \%$ and $81.9 \%$. These high prevalences corroborate the fourth hypothesis of the present research, warning that CDA is a common behavior among couples, especially in relation to Control / Monitoring (Caridade \& Braga, 2019; Van Oytsel et al., 2017c; Zweig et al., 2013).

Although important findings were found, the present study has limitations; in the first place, we note the lack of representativeness of the sample (nonprobabilistic), being recruited online, maybe attracting people of greater interest in the subject, not reflecting the composition population size and sample size. However, this limitation is also highlighted in the original CDAQ elaboration study (Borrajo et al., 2015a).

Secondly, because it is a self-report instrument related to violence, there may have been a bias of social desirability that influences participants to respond in a tendencious way (Stöber, 2001), thus requiring a greater control of this variable. Therefore, it is recommended that future studies overcome such gaps using other samples (for example: teenagers); as well as, improve the CDAQ, verifying different psychometric parameters such as: temporal stability (test-retest), discriminant validity, criterion and predictive, factorial invariance.

However, such aspects do not minimize the collaboration of this study, and we hope it offers a relevant contribution by offering the Brazilian context the adaptation of a first measure, with satisfactory psychometric qualities, to evaluate CDA evidencing an emergent phenomenon. Furthermore, the availability of this instrument can be useful for the context of research and interventions around related topics such as: VPI, relationship satisfaction; and other cyberbullying (cyberbullying, cyberstalking, sexting). In addition, for both preventive programs and clinical practice with situations of online abuse, this instrument can be a way of identifying cases of violence, sometimes not found by measures that identify face-to-face violence.

\section{References}

Behnken, M. P., Duan, Y., Temple, J. R., \& Wu, Z. H. (2018). Injury and psychiatric disorder in low-income women experiencing bidirectional intimate partner violence. Violence and Victims, 33(2), 259274. doi: 10.1891/0886-6708.VV-D-15-00066.

Borrajo, E., Gámez-Guadix, M., Pereda, N., \& Calvete, E. (2015a). The development and validation of 
the cyber dating abuse questionnaire among young couples. Computers in Human Behavior, 48, 358-365. doi: 10.1016/j.chb.2015.01.063

Borrajo, E., Gámez-Guadix, M., \& Calvete, E. (2015b). Cyber dating abuse: Prevalence, context, and relationship with offline dating aggression. Psychological Reports, 116(2), 565-585.doi: 10.2466/21.16. PR0.116k22w4

Brown, T. A. (2006). Confirmatory factor analysis for applied research. New York: Guilford Press.

Byrne, B. M. (2010). Structural equation modeling with Amos: Basic concepts, applications, and programming. New York: Routledge.

Caridade, S. M., \& Braga, T. (2019). Portuguese Version of the Cyber Dating Abuse Questionaire (CDAQ)Questionário sobre Ciberabuso no Namoro (CibAN): Adaptation and psychometric properties. Análise Psicológica, 37(1), 93-105.doi: 10.14417/ ap.1543.

Cava, M. J., \& Buelga, S. (2018). Propiedades psicométricas de la escala de ciber-violencia en parejas adolescentes (Cib-VPA). Suma Psicológica, 25(1), 5161.Doi: 0.14349/sumapsi.2018.v25.n1.

Cavalcanti, J. G., \& Coutinho, M .P. L. (2019). Abuso digital nos relacionamentos amorosos: urna revisão sobre prevalência, instrumentos de avaliação e fatores de risco. Avances en Psicología Latinoamericana, 37(2), 235-254.

Deans, H., \& Bhogal, M. S. (2017). Perpetrating Cyber Dating Abuse: A Brief Report on the Role of Aggression, Romantic Jealousy and Gender. Current Psychology, 1-6. doi: 10.1007/s12144-017-9715-4.

Durán, M., \& Martínez-Pecino, R. (2015). Ciberacoso mediante teléfono móvil e Internet en las relaciones de noviazgo entre jóvenes. Comunicar, 22(44), 159-167. doi: 10.3916/C44-2015-17.

Flach, R. M. D., \& Deslandes, S. F. (2017). Abuso digital nos relacionamentos afetivo-sexuais: uma análise bibliográfica. Cadernos de Saúde Pública, 33(7), e00138516. doi: 10.1590/0102-311X00138516.

Gouveia, V. V. \& Soares, A. K. S. (2015). Calculadora de validade de construto CVC, João Pessoa, PB: BNCS/ Universidade Federal da Paraíba. Retrieved from http://akssoares.com/psicometria/ calculadora-vme-e-cc
Hancock, K., Keast, H., \& Ellis, W. (2017). The impact of cyber dating abuse on self-esteem: The mediating role of emotional distress. Cyberpsychology: Journal of Psychosocial Research on Cyberspace, 11(2). doi: 10.5817/CP2017-2-2

Harrell, F. E., \& Dupont, C. (2018). Hmisc: harrell miscellaneous (Version 4.1.1) [Computer software]. Retrieved from https://cran.r-project.org/web/ packages/Hmisc/Hmisc.pdf

Hu, L-T., \& Bentler, P. M. (1999). Cutoff criteria for fit indexes in covariance structure analysis: Conventional criteria versus new alternatives. Structural Equation Modeling, 6, 1-55. doi: 10.1080/10705519909540118

Hutz, C. S., Bandeira, D. R., \& Trentini, C. M. (2015). Psicometria. Porto Alegre: Artmed Editora.

Kline, P. (2013). Handbook of Psychological Testing. London: Routledge.

Lorenzo-Seva, U., \& Ferrando, P. J. (2006). FACTOR: A computer program to fit the exploratory factor analysis model. Behavior Research Methods, 38, 88-91. doi: 10.3758/BF03192753

Marganski, A., \& Melander, L. (2015). Intimate partner violence victimization in the cyber and real world: examining the extent of cyber aggression experiences and its association with in-person dating violence. Journal of Interpersonal Violence, 1-25. doi: $10.1177 / 0886260515614283$

Melander, L. A. (2010). College students' perceptions of intimate partner cyber harassment. Cyberpsychology, Behavior, and Social Networking, 13(3), 263-268. doi: 10.1089=cyber.2009.0221.

Moraes, C. L. D., Oliveira, A. G., Reichenheim, M. E., Gama, S. G. N. D., \& Leal, M. D. C. (2017). Prevalência de violência física entre parceiros íntimos nos primeiros seis meses após o parto no Município do Rio de Janeiro, Brasil. Cadernos de Saude Publica, 33, e00141116. doi: 10.1590/0102$311 X 00141116$.

Moraes, C. L., Hasselmann, M. H., \& Reichenheim, M. E. (2002). Adaptação transcultural para o português do instrumento "Revised Conflict Tactics Scales (CTS2)" utilizado para identificar violência entre casais. Cadernos de Saúde Pública, 18(1), 163-76. doi: 10.1590/S0102-311X2002000100017

Psico-USF, Bragança Paulista, v. 25, n. 2, p. 285-296, abr./jun. 2020 
Muthén, L. K., \& Muthén, B. O. (2010). Mplus: The comprehensive modeling program for applied research (6th ed.). Los Angeles, CA: Muthén\&Muthén.

Neves, A., \& Duarte, C. (2015). Sintomas depressivos, resolução de conflitos e satisfação conjugal em indivíduos num relacionamento. Psicologia, Saúde \& Doenças, 16(3),331-344.doi:10.15309/15psd160305.

Paiva, T. T., Pimentel, C. E., \& Moura, G. B. D. (2017). Violência conjugal e suas relações com autoestima, personalidade e satisfação com a vida. Gerais: Revista Interinstitucional de Psicologia, 10(2), 215-227. Retrieved from https https://scholar.google.com. $\mathrm{br} / \mathrm{scholar}$ ?hl$=\mathrm{pt}-\mathrm{BR} \& a \mathrm{~s} \_\mathrm{sdt}=0 \% 2 \mathrm{C} 5 \& \mathrm{q}=$ violen cia + satisfa $\% \mathrm{C} 3 \% \mathrm{~A} 7 \% \mathrm{C} 3 \% \mathrm{~A} 3 \mathrm{o}+$ auto + estima $+\mathrm{c}$ onjugal\&btnG=

Pacico, J.C. \& Hutz, C.S. (2015). Validade. In C.S.Hutz, D.R.Bandeira \& C.M.Trentini (Orgs.), Psicometria (pp. 71-84). Porto Alegre: ArtMed.

R Development Core Team. (2011). R: A language and environment for statistical computing. Vienna, Austria: R Foundation for Statistical Computing.

Reed, L. A., Tolman, R. M., \& Ward, L. M. (2017). Gender matters: Experiences and consequences of digital dating abuse victimization in adolescent dating relationships. Journal of Adolescence, 59, 79-89. doi: /10.1016/j.adolescence.2017.05.015.

Revelle, W. R. (2018). Psych: Procedures for personality and psychological research (Version 1.8.4) [Computer software]. Retrieved from https://cran.r-project.org/ web/packages/psych/psych.pdf.

Rusbult, C. E. (1983). A longitudinal test of the investment model: The development (and deterioration) of satisfaction and commitment in heterosexual involvements. Journal of Personality and Social Psychology, 45(1), 101-117. doi: 10.1037/0022-3514.45.1.101

Runions, K., Shapka, J. D., Dooley, J., \& Modecki, K. (2013). Cyber-aggression and victimization and social information processing: Integrating the medium and the message. Psychology of Violence, 3(1), 9-26. doi: 10.1037/a0030511.

Sánchez, V., Muñoz-Fernández, N., \& Ortega-Ruíz, R. (2015). "Cyberdating Q_A": An instrument to assess the quality of adolescent dating relationships in social networks. Computers in Human Behavior, 48, 78-86. doi: 10.1016/j.chb.2015.01.006.
Shapiro, A., \& Ten Berge, J. M. (2002). Statistical inference of minimum rank factor analysis. Psychometrika, 67, 79-94. doi: 10.1007/BF02294710

Schnurr, M. P., Mahatmya, D., \& Basche, R. A. III. (2013). The role of dominance, cyber aggression perpetration, and gender on emerging adults' perpetration of intimate partner violence. Psychology of Violence, 3(1), 70-83. doi:10.1037/a0030601

Scorsolini-Comin, F., \& dos Santos, M. A. (2010). Satisfação com a vida e satisfação diádica: correlações entre construtos de bem-estar. Psico-USF, 15(2), 249-256. https://www.redalyc.org/ pdf/4010/401036080012.pdf

Smith-Darden, J. P., Kernsmith, P. D., Victor, B. G., \& Lathrop, R. A. (2017). Electronic displays of aggression in teen dating relationships: Does the social ecology matter?. Computers in Human Behavior, 67, 33-40. doi: 10.1016/j.chb.2016.10.015

Smith, K., Cénat, J. M., Lapierre, A., Dion, J., Hébert, M., \& Côté, K. (2018). Cyber dating violence: Prevalence and correlates among high school students from small urban areas in Quebec. Journal of Affective Disorders, 234, 220-223.

Stöber, J. (2001). The Social Desirability Scale-17 (SDS-17): Convergent validity, discriminant validity, and relationship with age. European Journal of Psychological Assessment, 17(3), 222-232.doi: 10.1027//1015-5759.17.3.222

Tabachnick, B. G., \& Fidell, L. S. (2013). Using multivariate statistics (6th ed.). Boston, MA: Allyn and Bacon.

Timmerman, M. E., \& Lorenzo-Seva, U. (2011). Dimensionality assessment of ordered polytomous items with parallel analysis. Psychological Methods, 16(2), 209-220.doi: 10.1037/a0023353

Troxel, W. M., Braithwaite, S. R., Sandberg, J. G., \& Holt-Lunstad, J. (2017). Does improving marital quality improve sleep? Results from a marital therapy trial. Behavioral sleep medicine, 15(4), 330-343. doi: 1 0.1080/15402002.2015.1133420

Van Ouytsel, J., Ponnet, K., \& Walrave, M. (2016). Cyber dating abuse victimization among secondary school students from a lifestyle-routine activities theory perspective. Journal of Interpersonal Violence, 0886260516629390. doi: $10.1177 / 0886260516629390$. 
Wachelke, J. R., De Andrade, A. L., Souza, A, M., \& Cruz, R. M. (2007). Estudo complementar da validade fatorial da Escala Fatorial de Satisfação em Relacionamento e predição de satisfação global com a relação. Psico-USF, 12 (2), 221-225.doi: 10.1590/S1413-82712007000200010.

Watkins, L. E., Maldonado, R. C., \& DiLillo, D. (2016). The Cyber Aggression in Relationships Scale: a new multidimensional measure of technology-based intimate partner aggression. Assessment, 1073191116665696.1 19. doi: 10.1177/1073191116665696
Wolford-Clevenger, C., Zapor, H., Brasfield, H., Febres, J., Elmquist, J., Brem, M., ... \& Stuart, G. L. (2016). An examination of the Partner Cyber Abuse Questionnaire in a college student sample. Psychology of Violence, 6(1): 156-162. doi:10.1037/a0039442.

Zweig, J. M., Dank, M., Yahner, J., \& Lachman, P. (2013). The rate of cyber dating abuse among teens and how it relates to other forms of teen dating violence. Journal of Youth and Adolescence, 42(7), 1063-1077. doi: 10.1007/s10964-013-9922-8.

Recebido em: 25/10/2018

Reformulado em: 24/04/2019

About the authors:

Jaqueline Gomes Cavalcanti is a Professor at the Institute of Higher Education of Paraíba. PhD student in Social Psychology at UFPB. Master in Social Psychology from Universidade Federal da Paraíba.

ORCID: http://orcid.org/0000-0002-3068-404X

E-mail: gomes.jaqueline@gmail.com

Maria da Penha de Lima Coutinho is a Coordinator of the Psychology course at the Institute of Higher Education of Paraiba. Volunteer professor of the Graduate Program in Social Psychology at the Universidade Federal da Paraíba and research fellow at CNPQ (1D). Psychologist graduated from UFPB (1978), Master in Health Psychology from UFPB (1986) and PhD in Clinical Psychology from the Universidade de São Paulo (2001). Post-doctoral studies completed at the Universidade Aberta de Lisboa, Portugal.

ORCID: https://orcid.org/0000-0003-3961-2402

E-mail:mplcoutinho@gmail.com

Anderson Mesquita do Nascimento is a PhD student in Social Psychology at UFPB. Master's degree in Social Psychology from UFPB.

ORCID: https://orcid.org/0000-0001-5093-8353.

E-mail: andermnascimento@gmail.com

Adriele Vieira de Lima Pinto is a PhD student in Social Psychology at UFPB. Master's degree in Social Psychology from UFPB.

ORCID: https://orcid.org/0000-0003-4126-1795

E-mail: adri.vlp8@gmail.com

Contact:

Av. Aragão e Melo, N. 861, Torre

João Pessoa-PB, Brasil

CEP: 58040-102 